\title{
PASTS AND FUTURES OF E. SAN JUAN, JR.
}

\author{
Charlie Samuya Veric \\ Ateneo de Manila University \\ cveric@ateneo.edu
}

\begin{abstract}
In this synthetic introductory essay, I consider the places of E. San Juan, Jr. as gleaned from the contributions to this special section: from San Juan's childhood in Manila and early education at the University of the Philippines at a time when veterans of the 1898 Revolution were still alive and peasant-based insurgency was on the rise; to his implicit contribution to the study of popular culture in the Philippines in the context of the emergence of nationalist struggle in the 1960 ; to his turning point as a materialist literary critic who wrote the study on Bulosan which coincided with his own decision to stay in the United States; to his participation in anti-Marcos organizing as an exile devoted to the radical future of his homeland; to his maturation as a theorist of race and racism in American institutions of higher education; to his contributions to the development of Filipino Critical Theory and environmental activism; to his systematic critique of Western capitalist modernity as a major scholar from the Third World; and finally, to his attempt to vernacularize international solidarity. I argue that San Juan's body of work constitutes a decolonizing archive that records the unfulfilled projects of liberation struggles from the last century. I also suggest that such an archive is noteworthy because it reveals the direction of Third World revolutionary critique from decolonization to the crisis of globalization today.
\end{abstract}

\section{Keywords}

Decolonization, E. San Juan, Jr., globalization, revolution, Third World

\section{About the Author}

A widely published scholar and poet, Charlie Samuya Veric holds a PhD in American Studies from Yale University and currently serves as the Associate Editor of Kritika Kultura. He is the author of Histories, the acclaimed and bestselling debut poetry collection, and of the forthcoming lyric sequence entitled Boyhood, both from Ateneo de Manila University Press. 
The year was 1987, shortly after the end of Ferdinand Marcos's dictatorship and the beginning of Corazon Aquino's presidency. Hope was in the air with the fall of a brutal regime, and E. San Juan, Jr. was at the Ateneo as a Visiting Fulbright Professor, giving a lecture. In a photograph from that period, San Juan is seated, wearing a dress shirt. His long sleeves are rolled up; the upper buttons undone, revealing a stout chest, his nipple visible. One hand holds a paper containing the text of a lecture, while the other extends outward, as if to reach into an invisible audience beyond the camera's frame. His mouth is half-open; his speech, frozen. The eyes, which peer from behind the thick glasses he is wearing, glisten.

About three decades later, San Juan would return to the Ateneo in the summer of 2015 to attend a symposium I organized in his honor, which was entitled "The Places of E. San Juan, Jr." This time around, he came wearing a pristine polo barong. Meanwhile in Malacañan, another Aquino, and yet another Atenean, wielded the highest power in the land as the controversy involving the murder of a Filipino transgender by a visiting American soldier raged across the country. Indeed, the hope that pervaded the nation three decades earlier had proved to be short lived, what with the long shadow of $9 / 11$ and the recent memory of the worst economic crisis since the Great Depression slouching toward the Philippines. The contributions in this special section had their origins in that event that celebrated the work of an exiled Filipino intellectual in a moment of global disquiet. Why such a symposium then? Why a special section on San Juan now?

In a complaint attributed to the late Benedict Anderson, the celebrated thinker was said to have remarked that three hundred years of Spanish colonialism had produced a José Rizal, whereas the American annexation of the islands and the fantasies of Hollywood have produced no one with a comparable stature. If the following essays are accurate, we shall begin to understand that one such person may now be in our midst. An intellectual of prodigious production and vatic insight, San Juan has authored extensive works as a literary critic, poet, fictionist, and public intellectual whose value in grasping the collective pasts and futures of the Filipino people in the homeland and the diaspora these essays seek to underscore. His body of work includes around 52 monographs, 21 volumes of poetry and fiction in English and Filipino, and 232 academic articles published between 1963 and 2015, most of which are listed in San Juan's curriculum vitae that this special section reproduces to ease the work of future scholars. Together, his writings represent some of the most sustained reflections on subaltern cultural politics, emphasizing the long tradition of Filipino revolts across the centuries and revealing their relevance to contemporary attempts to make sense of history in the context of decolonization and its critique of capitalist modernity in American image. 
Let it not be construed, however, that this special section claims to be exhaustive. If at all, it simply strives to highlight the fact that the work of understanding San Juan is just beginning, that his ideas still await the attention of far more competent commentators in far more auspicious times. For now, these essays open the needed conversation on San Juan's work that we may begin to fathom what it signifies for our pasts and futures as a people.

And so we begin with Efren Abueg who provides us with a biography of San Juan, as well as a chronicle of his contributions to the development of Filipino literature, a task that Abueg calls literary memory. In an essay that is part recollection, part criticism, Abueg, who is widely considered to be one of the best Tagalog writers, takes us from the childhood days of San Juan, who was born when the country was a de facto American colony, to his exile in the United States today where he continues to write his poetry in Filipino. What comes out is an invaluable account of the historical context that shapes San Juan's lifework, which becomes all the more vital given San Juan's refusal to write his autobiography. The selfie mode, as he puts it in his reply, is not to his liking. Abueg accordingly supplies us not only with the deepest biographical treatment of San Juan, but also with a personal testimony to their mutual attempt to develop the literature of a nation that endures in revolt.

Rolando Tolentino continues the autobiographical approach in Abueg. In particular, the former focuses not only on San Juan's influence on the study of popular culture but also on his own formation as an activist intellectual and educator. In an essay that is a cross between theory and autobiography, Tolentino describes how San Juan's thoughts have indirectly shaped the debates in popular culture, a field that Tolentino admits San Juan does not explicitly address in his writings. Yet Tolentino maintains that San Juan's emphasis on the idea of culture as the work of revolution has helped in maintaining the place of politics in cultural critique, a category that includes the study of popular culture itself. Moreover, Tolentino acknowledges the intellectual debts that he owes to San Juan for embodying the possibility of making scholarship responsive to the political life of a nation with a long tradition of political commitment among its intellectuals.

Michael Pante and Leo Nery bring us deeper into that tradition in their account of San Juan's foundational study of Carlos Bulosan. Pante and Nery take San Juan's Carlos Bulosan and the Imagination of the Class Struggle as their main topic, a work that Elmer Ordoñez considers in his own essay to be a turning point in San Juan's intellectual history. Their objective is to situate San Juan's literary criticism alongside the rise of peasant studies as a historical discipline in the Philippines and elsewhere. Pante and Nery specifically call attention to the emergence of anticolonial struggles, which coincided with the publication of San Juan's opus. And they emphasize that San Juan was the first to see Bulosan as an anticolonial figure 
on American shore. With this essay, Pante and Nery bridge the divide between the homeland and the Filipino diaspora, particularly in the United States, creating a narrative that unites the struggle at home with the aspirations of those torn off from their roots.

We may locate the essay of Ordoñez in this space between home and exile. In particular, he recalls his collaborations with San Juan in a time of persecution when the former had to flee the Philippines for safety. Bound by ties both personal and political, they found themselves organizing against the Marcos dictatorship in North America. Ordoñez, who lived at that time in Montreal after narrowly escaping his deportation to the Philippines from Malaysia, got in touch with San Juan in Connecticut. Together, they exposed the excesses of Marcos and circulated underground literature from the communist insurgency in the homeland. Along the way, Ordoñez highlights the productive relation between nationalism and internationalism, naming the necessity to see political work as situated, yet one that also goes beyond political and geographic borders. He consequently affords us a flexible understanding of the domestic, which may simultaneously refer to the originary homeland or to the place where the exile remains. Suspended between two countries, the exile's domicile becomes everywhere, a point that becomes salient in San Juan's case.

It is fitting, then, that we continue with the essay of Rachel Peterson and Joel Wendland who look into San Juan's contributions to higher education in the United States, a work that he is able to accomplish as an American citizen. It bears pointing out that the best years of San Juan's life as an intellectual have been devoted to the issue of race, a topic that resonates well in American domestic settings. But unlike other approaches to these questions in such fields as Cultural Studies, American Studies, Ethnic Studies, and African American Studies where a culturalist stance dominates, San Juan, Peterson and Wendland stress, keeps a materialist position that considers class as a significant lens with which to understand the historical experience of race. But what does race have to do with the Philippines where the issue is marginal at best? It is easy to say that San Juan's turn to race is a concession to the realities of the American academy, but Peterson and Wendland are quick to caution that such a reading may not only be reductive, but also tendentious. They stress the fact that San Juan's analysis of race and racism draws on the legacy of anticolonial struggles in the Philippines and the rest of the world. And to grasp this is to appreciate materialist categories such as totality and uneven development, concepts that I parse more fully in my own essay. Hence, San Juan succeeds in addressing an "American issue" without obscuring the continuing pertinence of anticolonialism, effectively turning the foreign into the domestic by other means. 
Michael Viola builds on such an assumption: namely, the power of the periphery to reimagine politics at the center of power. Viola attempts in particular to develop the philosophical foundations of what he terms Filipino Critical Theory in our $21^{\text {st }}$ century context wherein the logic of global accumulation generates the dispersal of vulnerable populations and the destruction of the natural habitat. The Philippines, Viola suggests, is a significant test case for rethinking the nature of politics wherein the question of anticolonial self-determination provides helpful models for enacting environmental activism. More specifically, he argues that environmental activism, especially those involving the Filipino diaspora, has much to learn from anticolonial organizing in the Philippines, a country that not only suffers from environmental plunder intensified by global capital, but also stands to suffer the most from climate change due to its location in the Pacific. By twinning historical demands for self-determination in the homeland and Filipino American environmental activism abroad, Viola remedies a gaping absence in San Juan's body of work that the latter himself readily admits in his response to the essays in this special section - the question of the environment. But instead of pitting politics against nature, Viola comes up with a surprising conjunction between the two, bringing their continuities to the fore.

But how does the Philippines figure in the global scramble for environmental plunder that attends Western expansion into Asia, Africa, and Latin America? What rationality is abetting its long history of civilizing barbarism? How does San Juan help us to confront its violent legacies? The answers lie in Kenneth Bauzon's reconstruction of the history of capitalism from the period of European colonialism all the way to the emergence of the United States as an imperial power following the conquest of the Philippines and the thwarting of the legacies of the 1898 Revolution against Spain. Expansive in reach, grand in ambition, and experimental in temperament, Bauzon assembles the touchstones in the political philosophy of Western capitalism from John Locke to William McKinley, surveying its development from the conversion of the commons, to the rise of the slaveplantation complex, to the fortification of class and the construction of gender and race, to the recapitulation and reinvention of colonialism, to the advent of United States imperialism and its attendant avowals of exceptionalism. Having set this scaffolding in place, Bauzon proceeds to undo its claims, citing freely from San Juan's works that come as discursive notes, epigraphs, quotations, riffs. In doing so, Bauzon calls attention to the ways in which San Juan's critiques from the periphery-embodied by the literal marginality of the citations-eat away at the foundations of capitalist rationality to reveal its poverty. The result is an essay that reminds us of San Juan's profound engagement with Western thought to arrive at a revolutionary form of Filipino being and becoming in the world. 
My own intervention in this special section similarly explores the power of San Juan's critique from the periphery and the radical opportunities it offers in rethinking the received wisdom of freedom and solidarity in the West. Where Bauzon considers the global history of capitalism, I look into the possibilities of planetary thinking from the periphery, focusing on San Juan's decolonizing engagements with Marxist conceptions of totality and uneven development. Using a less studied but defining text in his archive, The Radical Tradition in Philippine Literature, I examine the conjunction of vernacularism, Marxism, and decolonization as world historical events that constitute the heretofore untheorized imagination of the vernacular as planetary, which San Juan calls the New International. A lot is at stake, I argue, in delineating the New International as the emergence of a planetary thinking whose conditions of possibility are inextricably linked with subaltern desires for freedom. For the first time in history, international solidarity arises from a nonEuropean context, one that imagines a superordinate form of community that hopes to end the experience of exclusion and anomie. That is to say, the historical uniqueness of New Internationalism lies in the fact that it highlights the planetarity of the vernacular, a decolonizing imagination that offers an alternative to the kind of solidarity that comes from above, one that ultimately resists the capture of dispossessing instrumentality.

With such an essay, we come full circle in our attempt to mark the places of San Juan. From his childhood in Manila and early education at the University of the Philippines at a time when veterans of the 1898 Revolution were still alive and peasant-based insurgency was on the rise, to his implicit contribution to the study of popular culture in the Philippines in the context of the emergence of nationalist struggle in the 1960s, to his turning point as a materialist literary critic who wrote the study on Bulosan which coincided with his own decision to stay in the United States, to his participation in anti-Marcos organizing as an exile devoted to the radical future of his homeland, to his maturation as a theorist of race and racism in American institutions of higher education, to his contributions to the development of Filipino Critical Theory and environmental activism, to his systematic critique of Western capitalist modernity as a major scholar from the Third World, we close with an essay that exemplifies San Juan's heroic union of homeland and exile: the vernacularizing form of international solidarity, at once rooted in the homeland and relevant to all dispersed and deracinated communities across the planet today. It is a remarkable trajectory, encompassing such a wide range of fields as Philippine Studies, Ethnic Studies, Cultural Studies, American Studies, African American Studies, Environmental Studies, Popular Culture, Critical Theory, Political Philosophy, World Literature, and Marxism, to name a few that the essays in this special section will discuss shortly. 
One could suppose that this inventory suffices in showing how wide-ranging San Juan's interventions are. But a careful reader would pause and reconsider. For one can think of the following topics that still require the scrutiny of others: his sustained writings on such figures as Rizal, Nick Joaquin, José Garcia Villa, Sherwood Anderson, Benedict de Spinoza, Charles Sanders Peirce, Antonio Gramsci, Mikhail Bakhtin, Georg Lukacs, C.L.R. James; his significant contributions to the Philippine canon of poetry in English and Filipino; his work as a fictionist; his foundational role in the emergence of Filipino American Studies; his forays into such interdisciplinary fields as critical theory, diaspora, feminism, Filipino psychology, and visual culture; his treatises on Irish, African, and Latin American writers; his classic study on Oscar Wilde; his engagements with modernism, especially with T.S. Eliot and Ezra Pound; his creative work's translation into major world languages including Italian, Spanish, Chinese, and Russian; his reflections on the politics of Filipino as a national language; his body of critical work and its reception in the Philippines; his stature as a major Third World cultural critic; and his critique of postcolonial orthodoxy, among others.

Yet more blind spots remain. As San Juan himself admits in his response that doubles as a metacommentary on the authorial self, the last four decades have seen his energies being consumed by anti-Marcos organizing and the subsequent critique of the institutions of racism in the United States. Consequently, he has neglected urgent questions in the Philippines such as the analysis and exploration of indigenous culture in the critical study of Philippine literature, the folklore of ethnic communities like the Lumad and the Moro in Mindanao, and the technologies of mass media. His publication history bears this out. After releasing his book on the art of poetry in 1971, Ang Sining ng Tula, it would take San Juan more than four decades before he got around to publishing another collection of criticism in Filipino, Lupang Hinirang, Lupang Tinubuan, which came out in 2015. It is not difficult to imagine that his residency in the United States has played a role in creating such blind spots. San Juan must have been aware of this. In his writings, he would often refer to himself as an exile in "the belly of the beast," a remark that may strike others as part apology, part defense. What aggravates the issue is the fact that much of San Juan's exile is spent in an ivory tower, namely, the American university. Situated thus, San Juan is left with no choice but to fix his gaze on affairs that matter to the American center, and this he does to the neglect of certain topics relevant to the Philippines.

But our task today is not to castigate San Juan and prop up the divide between the homeland and its diaspora. Rather, our duty is to understand how such divides become productive, generating unseen possibilities for the separated. So, what resources become available to an exile thrown between the beast and the ivory tower? The answer is language and San Juan's turn to the mother tongue is his 
attempt to return symbolically to his homeland. It is in this context that one needs to understand his recent decision to write more consistently in Filipino, the same language that he uses in his response to the essays here. It is also in this context that one can understand his steady production of Filipino poetry collections in his late years in the United States, some of which are handcrafted, painstakingly designed and bound by him in limited editions, not to mention the poems he regularly sends to journals and magazines in the Philippines for publication. Not surprisingly, he devotes his remaining days to the examination of such neglected issues in his oeuvre in the context of what he calls the crisis of globalization. As of this writing, he is in the process of completing a study on early Filipino classics-namely, the vernacular novels of Faustino Aguilar, Lope K. Santos, Valeriano Hernandez Peña, Lazaro Francisco, Iñigo Ed. Regalado, all the way through Genoveva Edroza Matute and Liwayway Arceo, some of which can be found in the Beinecke Rare Books Library at Yale University-to fill a major gap in his lifework.

The gaps notwithstanding, his body of work as a whole is astonishing, one that requires new methodologies to do justice to its dizzying range and density. A quick look at his curriculum vitae is enough to send the most astute of readers into fits of anxiety. His partner and interlocutor, Delia D. Aguilar, would confess in her own piece that she has met few individuals who possess the breadth and depth of San Juan's learning. How to write about San Juan, then? In this special section, the individual contributions determine the form of discourse that suits their goal. For to write about San Juan is to think in experimental modes as a matter of necessity. The existing forms of scholarship are simply not adequate to the flights of his thoughts. So, there are critical essays to be found here, strictly conforming to the demands of conventional scholarship. There are personal essays, too, that delight in their open-endedness. Then there are those in between, even a conceptual photographic collage made by San Juan which, to me, mirrors his sensibility as an experimental poet; those that fall under this type are a cross between the requirements of scholarship and the recognition of its inadequacies. True to San Juan's oeuvre, the contributors come from both sides of the Pacific, representing different generations and races, using different languages, speaking on behalf of the struggle in the homeland and the resistance in empire. Given this structure, an ecology that reflects the revolutionary force of Filipino world making, we become closer to the spirit of San Juan's body of work: insistent, unruly, risky.

Taken together, the essays in this special section underscore the great importance of San Juan's ideas, highlighting the scope of his thinking that serves as a virtual catalog of the unfinished revolutions and dreams for human liberation from the previous century. Indeed, his thoughts constitute a decolonizing archive, a record of the anti-colonial aspirations of his people who continue to wage the world's longest-running insurgency and one of the few remaining full-fledged revolutions 
in our time. This archive is consequently significant for it carries into the future the permanency of a revolutionary past. It is not exaggeration to say that the direction of the continuing struggle in the country can determine the future of revolutionary ideas and practices not only as a spirit but also as a living force shaping human history. What is more, San Juan's development as an intellectual coincides with the historical trajectory of the United States as the last superpower in the world, namely, his growth as an intellectual who came of age in the era of decolonization runs parallel to the golden years and decline of American hegemony that begins with the triumph of Pax Americana after the Second World War and concludes tentatively with its crisis today. All the while, there is the Philippine insurgency that stands as an open resistance to capitalist modernity as a whole. Seen this way, anyone who seeks to understand the modern lifetimes of imperial ascendancy, as well as the questions posed to its authority, cannot afford to ignore San Juan who represents one of the last remaining thinkers who personally witnessed the anti-colonial revolts that had swept over Asia, Africa, and Latin America. That he has survived other key figures from his generation, including Amilcar Cabral and Frantz Fanon, compels us to consider his ideas even more seriously because they document the direction of Third World revolutionary critique from decolonization to the contemporary crisis of globalization. If Cabral and Fanon spoke to the declining empires of their time, namely Portuguese and French, San Juan's writings as a whole document the full emergence, pinnacle, and crisis of American power from a dual standpoint: from the heartland of empire as well as from the defiant countryside of his homeland. Thus, the critique that San Juan offers is robust in its capacity to provide a penetrating analysis of the corresponding dynamics of power and resistance, one whose scope is planetary, crossing back and forth between homeland and empire in its attempt to create a more just community of equals. That he comes from a former American colony, and some would say a neocolony, strengthens his critique all the more for the intimate insight it provides on the workings of empire and the struggles that are waged in the name of decolonizing freedom.

Still, it must be said that this special section is not meant to proclaim the sainthood of San Juan or to sing praises to his genius. San Juan himself cautions against such follies, suggesting that whatever contribution he has made to the archive of progressive thought he owes to the people's movement and select members of the anti-Marcos coalition in the United States and nationalists like Renato Constantino, Amado V. Hernandez, Teodoro Agoncillo, Jose Diokno, Jose Maria Sison, Maria Lorena Barros, as well as to the martyrs of the struggle for social justice, national democracy, and genuine sovereignty. For San Juan, the individuality of an author pales in comparison with the lives of ordinary people. He makes it exceedingly clear: the self is superfluous, which he would rather regard as an error, illusion, or empty signifier that only history has the power to save. Let 
it be said accordingly that we are not in search of heroes, not looking for another Rizal of our time. Pity the country that needs heroes, Bertolt Brecht warns.

What, then, are we marking if individual authorship, as San Juan claims, is just a conceit? This brings us to Aguilar's meditation on the virtues of memory, and to the end itself of this introduction. In her essay, Aguilar recounts a visit to Escolta, Manila's former top shopping district where a young San Juan had once bought her an ID bracelet as a lover's gift. On the way back to Balay Kalinaw, Aguilar noticed that her prized article of jewelry was missing. Aguilar and San Juan were in town for a short holiday then, a pilgrimage that became more frequent following their retirement. And so what was meant to be a memory walk turned out to be an occasion for grappling with loss: the ruins of a place viewed against its old glory, the disappearance of an ID bracelet that served as the couple's last connection to a vanished time of innocence. Drawing on this story, Aguilar reflects on the ravages of history and the possibilities for deliverance. Ours is a contradictory world, she says, and our redemption lies in our capacity to witness. For in witnessing this world, we come alive in our freedom to change it radically. The experience of witnessing, then, is memory work itself: to witness is to remember.

So it is with this special section whose hope is to remember a life rooted in the contradictions of our time. What do we witness? What memory do we keep alive? This takes us to the photograph in the beginning. San Juan extends his hand in space, his mouth shaping the utterance of a voice. The hand hails witnesses to come, the voice echoing the radical dreams of his disinherited homeland. I have another way of putting it. The picture invites us to witness a mind that finds its place in the lives of ordinary people who rise and resist to create their dwelling place in history. If the essays that follow are true, nothing less than the achievement of earthly paradise is at stake in San Juan's invitation to collective remembrance. So we remember and sing, to paraphrase Joaquin, because life is short and the revolution, long. 